\title{
Numerical analysis of chemically foamed thick- walled PA66 GF30 moldings
}

\author{
Natalia Konczal $^{1 *}$, Piotr Czyżewski ${ }^{1}$, Bartosz Nowinka ${ }^{1}$ \\ ${ }^{1}$ Bydgoszcz University of Science and Technology, Faculty of Mechanical Engineering, Department \\ of Manufacturing Techniques, Al. prof. S. Kaliskiego 7, 85-796 Bydgoszcz, Poland
}

\begin{abstract}
The paper presents a numerical analysis of thick-walled PA66 GF30 moldings with the addition of a chemical blowing agent with a content of $1-3 \mathrm{wt} \%$, and the obtained results were compared with the real object. Computer simulations were performed using Moldex $3 \mathrm{D}^{\circledR}$ software. Based on the numerical analysis, it was found that regardless of the dose of the blowing agent used, the largest pores were place in the core of the sample. Moreover, it was found that the size of the pores depends on their number in the cross-section of moldings. Compositions containing a higher crosssectional pore density were characterized by smaller pore sizes. The results of the computer simulation also showed that increasing the blowing agent dose above $2 \mathrm{wt} \%$ does not significantly affect the size of the pores in the structure. The experimentally determined pore size of the composition containing $3 \mathrm{wt} \%$ chemical blowing agent slightly differs from the pore size obtained based on numerical analysis.
\end{abstract}

\section{Introduction}

The foaming process of polymeric materials is often used in the plastics processing industry due to the numerous advantages of these materials and economic production aspects [1]. Component weight reduction, low processing shrinkage, and slight warpage contribute to better dimensional stability of the components. These materials also have low thermal conductivity and absorb sound [1-3]. The favorable properties of porous materials enable their use in the automotive industry, e.g. structural and shock-absorbing elements in cars, in the aviation industry, e.g. in aircraft structural elements, in biomedical engineering, and in construction. Packaging for food and other products, as well as sports accessories, are also made of materials with a foam structure [2-4]. The use of foam injection molding allows to significantly reduce the cycle time and reduce energy consumption [1].

In the injection process, the porous structure in the polymeric materials can be obtained by adding a supercritical fluid (SCF) (physical foaming) or a chemical blowing agent (CBA) (chemical foaming) to the polymer. The MuCell ${ }^{\circledR}$ technology is most often used in physical foaming. This technology depends on introducing supercritical carbon dioxide or nitrogen to the plasticizing system of the injection molding machine [5,6]. Micropores are formed as a result of the nucleation process of a large number of nuclei. This process is activated under

\footnotetext{
* Corresponding author: natalia.konczal@pbs.edu.pl
} 
the influence of a sudden and large pressure drop in the mold cavity [5]. In the process of chemical foaming, the porous structure is formed as a result of the thermal decomposition of the chemical blowing agent or in the effect of the reaction of the blowing agent with other polymer components and gas production [6]. After decomposition, most chemical blowing agents produce nitrogen or carbon dioxide [7]. Chemical blowing agents are divided into endothermic and exothermic. In industry, endothermic blowing agents are most often used due to the possibility of creating a porous structure with small pore dimensions. The microporous structure has better mechanical properties than standard pore structure. The use of endothermic blowing agents reduces the gas pressure inside the part and accelerates its cooling time. As a result, it shortens the cycle time [2,5]. The main difference between physical and chemical foaming is the density and size of the pores, which directly affect the properties of the products. In physical foaming, smaller pore sizes and better distribution in the polymer are obtained. As a result, the material produced in the process of physical foaming has a lower density and the mechanical properties are similar to the mechanical properties of a solid material $[3,8]$. The process of physical foaming is carried out on specialized production equipment, which is associated with greater financial outlays for the production of porous materials than in the case of using chemical foaming $[3,5]$.

Plastic injection molding technology, due to the complex nature of the process is analysed with the use of specialized CAD / CAM / CAE software [9]. Examples of engineering programs for simulating the injection molding process are Moldex $3 \mathrm{D}^{\circledR}$, Cadmould, Autodesk Moldflow. To simulate the injection molding process, the $3 \mathrm{D}$ model of the molded part, properties of the processed plastic, and process parameters are required [2]. The numerical analysis enables the simulation of the phenomena occurring during the injection process, including simulation of plastic flow in the injection mold cavity, analysis of the mold cavity filling - injection and holding phases, as well as subsequent analysis of cooling, processing shrinkage, warpage and deformation of the molding [9]. Along with the development of techniques for the production of elements with the use of polymer materials in numerical analysis programs, apart from the simulation of the classical injection molding process, there are also new variants of this process, e.g. Microcellural Injection Molding, BiInjection Molding, Co-Injection Molding, Resin Transfer Molding [10].

The aim of the research was to carry out a numerical analysis of the injection process with the use of chemical blowing agent PA66 GF30 moldings. The influence of CBA content on the microcellular structure of a thick-walled part was determined. The results of the computer simulation were compared to the structures obtained in the conditions of the real experiment.

\section{Research methods}

In the tests, polyamide PA66 GF30 Technyl AR 130/1 (Rhodia, France) containing $30 \mathrm{wt} \%$ of short glass fibre was used. The density of the polymer was $1370 \mathrm{~kg} \cdot \mathrm{m}^{-3}$, its melting point was $263^{\circ} \mathrm{C}$, water absorption was $0.8 \mathrm{wt} \%$ (at $230^{\circ} \mathrm{C}, 24 \mathrm{~h}$ ). Before use, the material was dried in a Binder FED 115 dryer at $80^{\circ} \mathrm{C}$ for 4 hours. The endothermic chemical blowing agent Hydrocerol ${ }^{\circledR}$ ITP825 (Clariant) was an addition to PA66 GF30. The blowing agent contained $40 \%$ of the active substance and was in the form of granules. Its decomposition temperature was $200^{\circ} \mathrm{C}$. The content of the chemical blowing agent in PA66 GF30 was 1,2 and $3 \mathrm{wt} \%$. The porous test specimens were injection molded using an ENGEL e-victory 110 hybrid injection molding machine. The injection process parameters are presented in Table 1 . The samples were produced in a two-cavity cold-runner injection mold. The size of the molding cavities corresponds to 1.5-fold (small sample) and 2-fold (large sample) size of test samples made according to PN-EN ISO 527-2 type 1B. The dimensions of the test samples are presented in Figure 1. The injection mold base was made of steel 1.1730, and the molding plates with dimensions of $290 \mathrm{~mm}$ x $235 \mathrm{~mm}$ where made of steel 1.2312 . The mold runner 
was $183 \mathrm{~mm}$ long and $11 \mathrm{~mm}$ width. In the mold cavity a gap gate with the dimensions of 24 $\mathrm{mm} \times 4.2 \mathrm{~mm}$ (large piece) and $21 \mathrm{~mm}$ x $4.1 \mathrm{~mm}$ (small piece) (wide x deep), respectively was used. Cooling channels were made in forming plates symmetrically to the parting plane and parallel to the flow direction of the material in the mold.


Fig.1. The geometry and the real view which of the samples were produced in microcellular injection molding technology.

Table 1. Injection molding process parameters.

\begin{tabular}{lc}
\hline \multicolumn{1}{c}{ Process parameters } & Value \\
\hline limit injection pressure & $200 \mathrm{MPa}$ \\
filling time & $1.4 \mathrm{~s}$ \\
flow rate & $80 \mathrm{~mm} / \mathrm{s}$ \\
melt temperature & $280^{\circ} \mathrm{C}$ \\
packing time & $0.5 \mathrm{~s}$ \\
cooling time & $50 \mathrm{~s}$ \\
mold temperature & $90^{\circ} \mathrm{C}$ \\
temperature of the plasticizing & $280^{\circ} \mathrm{C}, 280^{\circ} \mathrm{C}, 250^{\circ} \mathrm{C}, 230^{\circ} \mathrm{C}, 40^{\circ} \mathrm{C}$ \\
system zones $\left(\mathrm{Tn}, \mathrm{Tz}_{3}, \mathrm{Tz}, \mathrm{Tz}, \mathrm{Tf}\right)$ & \\
\hline
\end{tabular}

Microcellular Injection Molding (MIM) process simulations were made with use of Moldex $3 \mathrm{D}^{\circledR}$ (CoreTech System Co., Ltd., Taiwan). Numerical analysis was performed on the basis of the volumetric model. This model was used to define the mold cavity and the runner channel. Table 2 presented the simulation parameters. The MIM simulations were performed using the data used in the real study. The chemical blowing agent (CBA) was described by the parameters: produced gas amount cc/g and main gas percentage $\left(\mathrm{N}_{2} / \mathrm{CO}_{2}\right)$. The produced gas amount was assumed to be $280 \mathrm{cc} / \mathrm{g}$ and the main gas $60 \%\left(\mathrm{~N}_{2} / \mathrm{CO}_{2}\right)$. The pore size in the cross-section of the molded part was measured using points spaced every $10 \%$ of the thickness value of each test sample. The scheme of the distribution of the measurement points in the cross-section of the sample is shown in Figure 2.

The pore size in the real samples was measured on a Keyence VHX 7000 optical microscope. The test pieces were taken from the center of the samples with a thickness of 6 $\mathrm{mm}$ and $8.4 \mathrm{~mm}$ and a chemical blowing agent content of $3 \mathrm{wt} \%$. The breakthroughs were 
prepared by impact-breaking test pieces previously immersed in liquid nitrogen. The pore size was measured in the core of the moldings.

Table 2. Simulation parameters in Moldex $3 \mathrm{D}^{\circledR}$.

\begin{tabular}{lc}
\hline \multicolumn{2}{c}{ Simulation parameters } \\
\hline Mesh type & Irregular triangular \\
Element size & $2.0 \mathrm{~mm}$ \\
Elements of solid mesh & 116555 \\
Nodes of solid mesh & 55428 \\
\hline
\end{tabular}

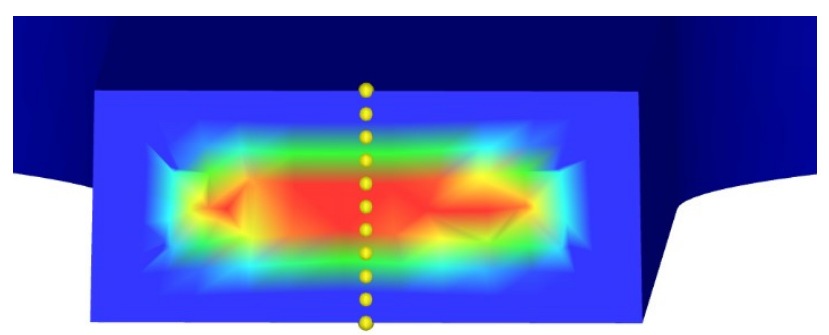

Fig.2. Arrangement of measurement points in the section of the molded part.

\section{Results}

The results of the simulations performed are presented from Figure 3 to Figure 5. Figure 3 presented the average pore size in the subsequent layers of the sample with a thickness of 6 $\mathrm{mm}$. The smallest pore size was obtained for the sample containing $3 \mathrm{wt} \% \mathrm{CBA}$. In the skin layer of the molding (distance range from $0 \%$ to $20 \%$ and $80 \%$ to $100 \%$ ), the size of the pores is the smallest, while the closer to the core of the molding, the size of the pores increases. This tendency is noticeable for all the blowing agent content and is consistent with the phenomenon of pore size in individual layers of the molding described in the literature [5].

Figure 4 shows the average pore size in individual zones of the molding with a thickness of $8.4 \mathrm{~mm}$. The size of the pores in the skin layer and the core of the molded part is similar to the sample with a thickness of $6 \mathrm{~mm}$ - the largest pores are in the core of the molded part. The composition containing $1 \mathrm{wt} \%$ of the chemical blowing agent obtained a pore size equal to $500 \mu \mathrm{m}$. This is the upper limit of pore growth registration in the Moldex $3 \mathrm{D}^{\circledR}$ software. In the case of $8.4 \mathrm{~mm}$ thick model the finest cells were obtained with the use of $2 \mathrm{wt} \%$ of CBA. The smallest pore size for the $8.4 \mathrm{~mm}$ thick model was obtained by the sample containing $2 \mathrm{wt} \%$ of the blowing agent. The smallest pore size for a composition containing a $2 \mathrm{wt} \%$ blowing agent may be caused by a higher cell density in the cross-section of the molding (Figure 5). The samples with a thickness of $6 \mathrm{~mm}$ and the content of blowing agents 1 and 3 $\mathrm{wt} \%$ have a higher cell density in the core of the molding than samples with a thickness of $8.4 \mathrm{~mm}$. The cell density in the section of the molded part is closely related to their size in a given layer - the lower the pore density, the larger their size [11]. The $6 \mathrm{~mm}$ thick sample foamed with the use of $1 \mathrm{wt} \%$ of CBA indicated smaller pores in the noticed core zone than the corresponding $8.4 \mathrm{~mm}$ thick sample. The pore size in the core of the sample for a composition containing $3 \mathrm{wt} \%$ of blowing agents for both the $6 \mathrm{~mm}$ and $8.4 \mathrm{~mm}$ thick models are similar. 


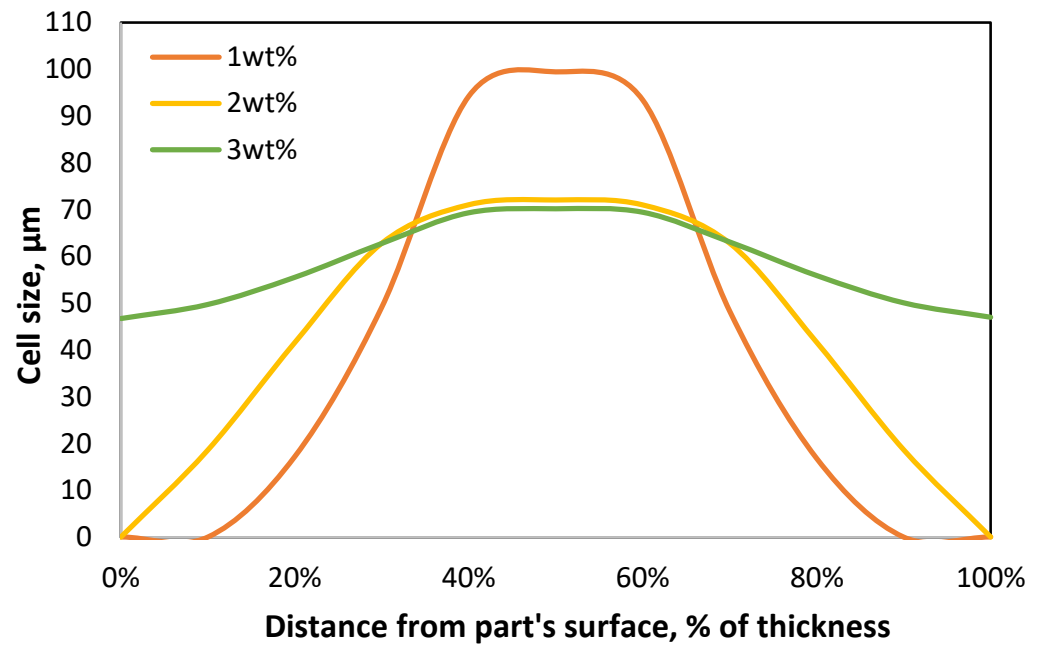

Fig.3. Cell size distribution in a $6 \mathrm{~mm}$ thick sample.

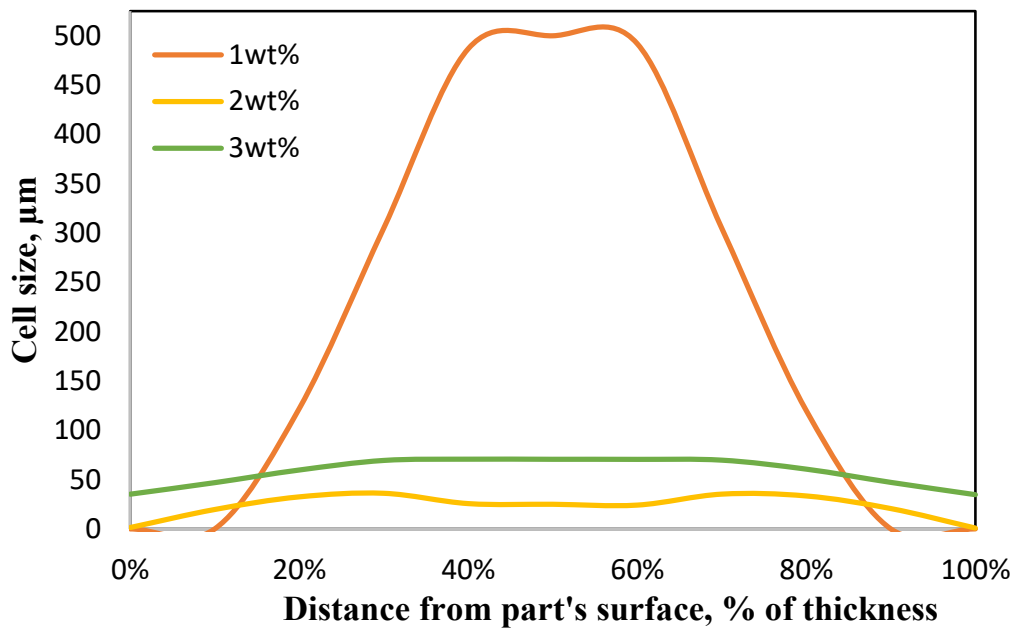

Fig.4. Cell size distribution in an $8.4 \mathrm{~mm}$ thick sample. 


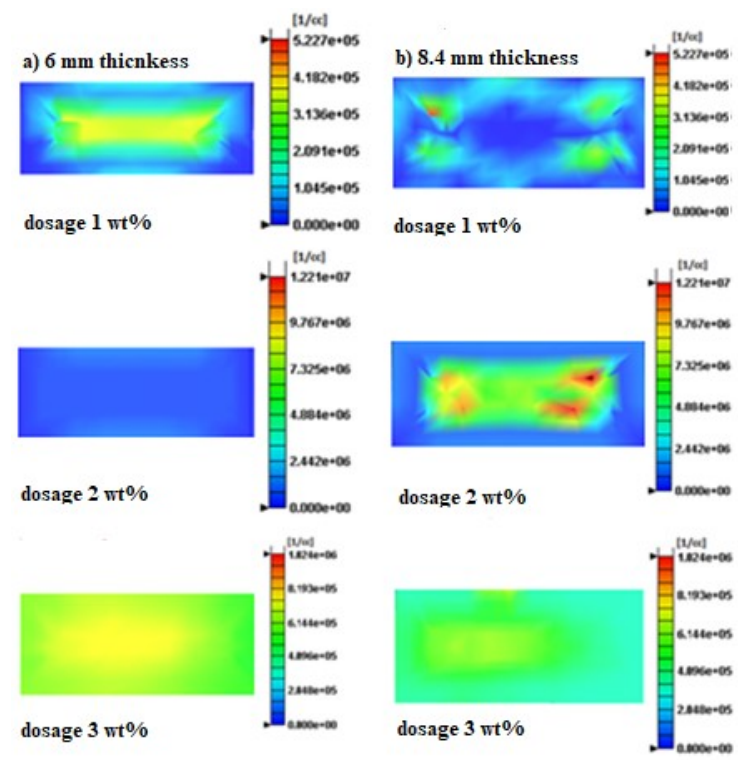

Fig.5. Cell density in a) $6 \mathrm{~mm}$ thick sample and b) $8.4 \mathrm{~mm}$ thick sample

The reality core structure of $6 \mathrm{~mm}$ and $8.4 \mathrm{~mm}$ thick moldings for the $3 \mathrm{wt} \%$ blowing agent content recorded using an optical microscope is presented on Figure 6. The microscopic measurements were performed on a limited random sample to show the influence of the thickness of the molding on its structure obtained in the real experiment. The pore size in the $6 \mathrm{~mm}$ thick piece ranges from $50 \mu \mathrm{m}$ to $69 \mu \mathrm{m}$, while in the case of $8.4 \mathrm{~mm}$ thick sample, the pore size is much larger and ranges from $70 \mu \mathrm{m}$ to $97 \mu \mathrm{m}$. In the computer simulation, the average pore size in the core of the molding for both the $6 \mathrm{~mm}$ and $8.4 \mathrm{~mm}$ thick samples are similar approximately equal to $70 \mu \mathrm{m}$. In real experiment, the pore size in the core of the moldings was different for both thicknesses. For the $6 \mathrm{~mm}$ thick molded part, the noticed pore size was smaller than in the numerical analysis. In the case of the $8.4 \mathrm{~mm}$ thick sample, the real pore size was larger than the simulation shows. Numerical analysis programs, despite the use of advanced computational algorithms, do not always present results consistent with reality [9]. 



Fig.6. The core structure of the molded parts registered for a thicknesses equal to 6 $\mathrm{mm}$ (upper picture) and $8.4 \mathrm{~mm}$ (lower picture).

\section{Conclusions}

Based on the numerical analysis of thick-walled PA66 GF30 moldings with the addition of a chemical blowing agent with a content of $1-3 \mathrm{wt} \%$, it was shown that for all chemical blowing agent content, the largest pores are found in the sample core. Moreover, it was found that the size of the pores depends on their number in the cross-section core of the specimen. Compositions containing a higher quantity of pores indicated a smaller pore size. In the case of the $6 \mathrm{~mm}$ thick model, the cell density in the core of the molding increased with the increasing content of the blowing agent in the composition. However, for a $8.4 \mathrm{~mm}$ thick molded part, the similar trend was not observed. The composition containing $2 \mathrm{wt} \%$ of blowing agent obtained the smallest pore size in $8.4 \mathrm{~mm}$ thick of molded part.

Increasing the dose of the chemical blowing agent above $2 \mathrm{wt} \%$ does not significantly affect the pore size. Moldings with a thickness of $6 \mathrm{~mm}$ and $8.4 \mathrm{~mm}$ with a blowing agent content of $3 \mathrm{wt} \%$ showed a similar pore sizes in a computer simulation.

Numerically determined pore size in both cases is comparable to the optically measured values. In the case of $6 \mathrm{~mm}$ thick specimen the highest measured pore showed of $69 \mu \mathrm{m}$, 
while the average pore size calculated by Moldex $3 \mathrm{D}^{\circledR}$ was $70 \mu \mathrm{m}$. However the average pore size in an injection molded sample surely has a significantly lower value.

Further research should be extended to a more detailed microscopic analysis of the composition containing $1 \mathrm{wt} \%$ and $2 \mathrm{wt} \%$ chemical blowing agents. It should also be checked whether, in real conditions, increasing the blowing agent dosage above $2 \mathrm{wt} \%$ results in an increase of the size of the pores in the core of the molding.

Thanks to CoreTech System Co.,Ltd. for providing Bydgoszcz University of Science and Technology with Moldex $3 D^{\circledR}$ software which allowed for conduction of the described experiment.

\section{References}

1. C.Hopmann, D.Sander, “ Characterisation of blowing agent loaded plastic melts for improved filling simulation of the foam injection moulding process", International Polymer Science and Technology, Vol. 43, No. 1, (2016)

2. Ch. Chung, S. Hwang, S. Chen, M. Lai, "Effects of Injection Molding Process Parameters on the Chemical Foaming Behavior of Polypropylene and Polystyrene" Polymers 2021, 13, 2331

3. B.Pavel, S.Nirav, B.Jiri, "Computer Analysis of Polyolefins Produced with Injection Molding Process Using Physical Blowing Agents", Materials Science Forum Submitted: 2017-09-21 ISSN: 1662-9752, Vol. 919, pp 299-306 (2018)

4. H. Weber, I. De Grave, E. Röhrl, V. Altstädt. Foamed Plastics. Ullmann's Encyclopedia of Industrial Chemistry, 1-54. (2016).

5. P. Palutkiewicz, T. Garbacz, „Ocena efektywności wybranych środków porujących w procesie wtryskiwania wyprasek z tworzyw termoplastycznych, Polimery $\mathrm{nr}$ 6, 62 (2017)

6. R. Heck III, W. Peascoe, "Blowing Agents" in EPSE 2nd ed., Vol. 2, pp. 434-446, Uniroyal Chemical Group (2011)

7. Reglero Ruiz, J. A., Vincent, M., Agassant, J.-F., Sadik, T., Pillon, C., \& Carrot, C. "Polymer foaming with chemical blowing agents: Experiment and modeling". Polymer Engineering \& Science, 55(9), 2018-2029 (2014)

8. D. Sykutera, P. Czyżewski, P. Szewczykowski, "The Microcellular Structure of Injection Molded Thick-Walled Parts as Observed by In-Line Monitoring”, Materials 13, 5464 (2020).

9. T. Jachowicz, B. Duleba, V. Krasinskyi, „Ocena technologiczności wyprasek wtryskowych na podstawie numerycznej symulacji wtryskiwania termoplastycznych tworzyw polimerowych" Przetwórstwo tworzyw 3 (2014)

10. http://support.moldex3d.com/r17/en/index.html (access 15.10.21)

11. Ruiz-Herrero, J. L., Estravis, S., \& Rodríguez-Perez, M. A. Polymeric Foams. In KirkOthmer Encyclopedia of Chemical Technology (pp. 1-39). John Wiley \& Sons, Inc. (2017). 